\title{
Korupsi, Indikator Makro Ekonomi, dan IPM terhadap Tingkat Kemiskinan di Indonesia
}

\author{
Palupi Lindiasari Samputra ${ }^{1)}$ \\ Adis Imam Munandar ${ }^{2}$ \\ ${ }^{1)}$ Pengajar Program Ketahanan Nasional, SKSG UI \\ ${ }^{2)}$ Pengajar Program Ketahanan Nasional, SKSG UI
}

\begin{abstract}
ABSTRAK
Penelitian ini bertujuan untuk mengetahui faktor-faktor penyebab tingkat kemiskinan di Indonesia, baik dampak positif maupun negatif. Terdapat tiga indikator utama yang digunakan untuk melihat seberapa besar dampak masing-masing indikator terhadap tingkat kemiskinan di Indonesia. Ketiga indikator tersebut diwakili oleh variabel-variabel ; IPM (Indeks Pembangunan Manusia), Korupsi (jumlah terpidana kasus korupsi) dan indikator makroekonomi (inflasi, PDRB per kapita, jumlah penduduk (sebagai variable control)). Metode penelitian yang digunakan adalah metode panel data, yang terdiri dari data tahun (2009-2013) dan data propinsi di Indonesia (28 propinsi). Model kemiskinan di Indonesia dapat dijelaskan melalui model Fixed effect GLS setelah melalui uji pemilihan model terbaik dan uji pelanggaran asumsi klasik.Hasil penelitian menunjukkan bahwa dari tiga indikator penyebab tingkat kemiskinan di Indonesia, hanya variabel PDRB per kapita secara statistik tidak signifikan pengaruhnya terhadap tingkat kemiskinan. Faktor-faktor lainnya dapat menjelaskan pengaruhnya terhadap tingkat kemiskinan secara signifikan. Terdapat dua pengaruh, yakni positif dan negative. Faktor yang mampu menurunkan tingkat kemiskinan di propinsi-propinsi Indonesia adalah IPM (semakin besar pengaruhnya di propinsi luar Sumatera dan Jawa-Bali), inflasi dan jumlah penduduk. Hanya variable korupsi yang berdampak positif terhadap meningkatnya tingkat kemiskinan di Indonesia. Perlu peran aktif pemerintah dalam mewujudkan program pengentasan kemiskinan melalui pembangunan manusia di seluruh propinsi Indonesia.
\end{abstract}

Klasifikasi JEL: D73, I32, C23

Kata kunci: Korupsi, Kemiskinan, panel data

\section{Corruption, Macro-economic Indicators, and HDI towards Poverty Rate in Indonesia}

\begin{abstract}
This study aims to identify the factors causing the poverty rate in Indonesia, both positive and negative impacts. There are three variables used in this study including HDI (Human Development Index), corruption (the amount of convicted corruption), and macro-economic indicators (inflation, GDP per capita, population). The variable of macro-economic indicators functioned as the control variable. This study used panel data method consisting of the data from 2009 to 2013 of 28 provinces in Indonesia. The model of poverty in Indonesia can be explained by Fixed Effect GLS model after passing the model selection and classic assumption collision testing. The results showed that among the three indicators, only the variable of GDP per capita having an insignificant effect on the poverty rate. Other factors have significant effects on thepoverty rate. There are two effects including positive and negative effects. The factors with the ability to reduce the poverty rate in Indonesia areHDI (greater effects in the provinces outside Sumatra and Java-Bali), inflation and population. Only the variable of corruption have a positive effect on the increasing poverty rate in Indonesia. The government needs to actively realize the alleviation of poverty program through human development in all provinces of Indonesia.
\end{abstract}

Classification JEL: D73, I32, C23

Keywords: corruption, poverty, panel data

${ }^{1)}$ upies77@gmail.com,palupi.1s@ui.ac.id

2)adis.imam@ui.ac.id, adis.munandar@gmail.com 


\section{LATAR BELAKANG}

Kemiskinan merupakan salah satu indikator yang paling mudah digunakan dalam menilai tingkat kesejahteraan suatu negara. Semakin tinggi persentase jumlah penduduk miskin mencerminkan makin rendahnya tingkat kesejahteraan negara tersebut. Namun pada kenyataannya tidak hanya tingkat kemiskinan saja yang menunjukkan kesejahteraan suatu negara, terdapat indikator lainnya yang tidak kalah penting, yaitu : IPM (Indeks Pembangunan Manusia), Tingkat Pengangguran dan Gini Ratio. Menurut Kamus Besar Indonesia (KBI) kemiskinan didefinisikan sebagai keadaan terjadi kekurangan hal-hal yang biasa untuk dipunyai, seperti : makanan, pakaian, tempat berlindung dan air minum. Hal-hal yang berhubungan erat dengan kualitas hidup.

Gambaran tingkat kemiskinan di Indonesia ditunjukkan pada grafik 1 dan 2, yakni gambaran tingkat kemiskinan di pulau Sumatera dan JawaBali, serta di luar pulau Sumatera dan Jawa-Bali. Hal ini bertujuan untuk membandingkan hasil kinerja perekonomian di kedua pulau tersebut. Berdasarkan data tingkat kemiskinan untuk propinsi Sumatera dan Jawa-Bali menunjukkan terdapat perbedaan yang cukup besar antara daerah Sumatera dengan Jawa-Bali. Propinsi Aceh, Sumatera Selatan, Bengkulu dan Lampung merupakan daerah-daerah dengan tingkat kemiskinan paling tinggi di Pulau Sumatera. Sedangkan di wilayah pulau Jawa-Bali, propinsi dengan tingkat kemiskinan tinggi adalah Yogyakarta, Jawa Tengah dan Jawa Timur. Namun Yogyakarta memiliki tingkat kemiskinan yang cukup resisten dibanding kedua propinsi lainnya.

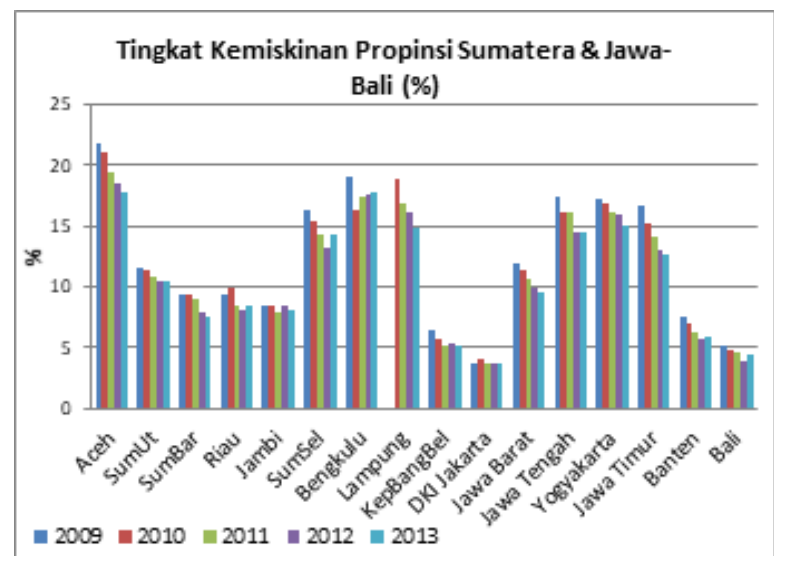

Grafik 1. Tingkat Kemiskinan (\%) Propinsi

Sumatera dan Jawa-Bali (sumber : bps.go.id)

Kenyataan tersebut menunjukkan bahwa tingkat kesejahteraan di Pulau Sumatera dan JawaBali kurang merata. Hal ini ditunjukkan oleh tingkat kemiskinan yang rendah masih didominasi oleh wilayah Ibu Kota di pulau Jawa, yakni DKI Jakarta. Dengan akses perekonomian di wilayah pulau Sumatera dan Jawa-Bali, baik infrastruktur maupun kedekatan dengan wilayah Ibu Kota negara, tidak menjamin tingkat kesejahteraan yang tinggi bagi propinsi-propinsi di pulau Sumatera.

Kondisi serupa juga terjadi di luar pulau Sumatera dan Jawa-Bali, yakni tingkat kemiskinan yang tinggi terjadi hampir disebagian besar propinsi luar pulau Jawa. Hal ini ditunjukkan pada grafik 2. Khususnya untuk propinsi Papua, Maluku, NTB dan NTT, yang sering disebut wilayah timur Indonesia.

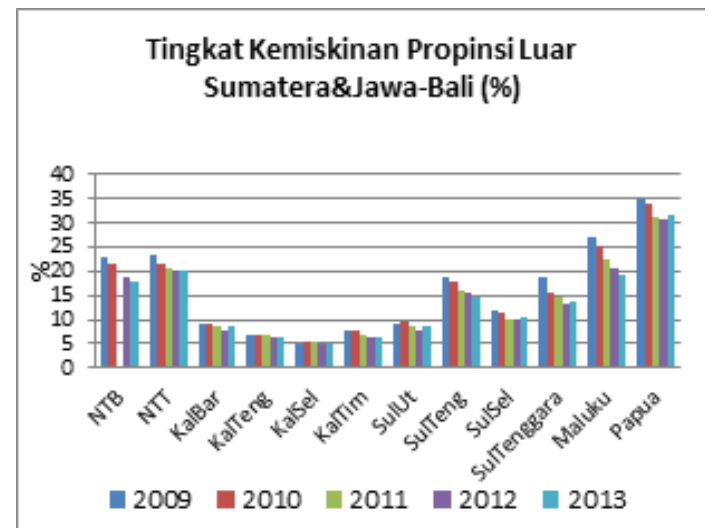

Grafik 2. Tingkat Kemiskinan (\%) Propinsi Luar Sumatera dan Jawa-Bali (Sumber : bps.go.id)

Wilayah Kalimantan merupakan daerah dengan tingkat kemiskinan yang rendah di luar pulau Sumatera dan Jawa-Bali. Dari data-data tersebut terlihat bahwa sebagian besar wilayah propinsi di Indonesia masih terbilang berada pada tingkat kemiskinan yang tinggi. Hanya beberapa propinsi saja yang telah mampu mencukupi kebutuhan warganya. Kenyataan ini patut menjadi perhatian penting bagi pemerintah dalam menilai kinerja perekonomian propinsi-propinsi di Indonesia. Karena belum adanya pemerataan kesejahteraan antar daerah di Indonesia. Kondisi ini terjadi akibat adanya dominasi perekonomian oleh propinsi-propinsi tertentu saja. Terdapat indikasi kurangnya kepedulian antar daerah di Indonesia sebagai satu kesatuan bangsa yang saling membantu satu sama lain. Oleh karena itu dibutuhkan pemahaman yang mendalam akan penyebab tingginya tingkat kemiskinan di sebagian besar propinsi di Indonesia, sehingga nantinya diharapkan dapat memecahkan permasalahan kemiskinan di Indonesia sesuai dengan kondisi masing-masing propinsi.

Hasil beberapa penelitian berkaitan dengan 
tingkat kemiskinan menunjukkan bahwa terdapat faktor penyebab kemiskinan yang berbeda antara desa dan kota di Indonesia. Berdasarkan hasil penelitian Kaplale (2012), Harahap (2002), Rusdati dan Resta (2013) menunjukkan bahwa penyebab kemiskinan di desa adalah menurunnya produktivitas tanaman, lapangan kerja yang sulit didapat, rendahnya tingkat pendidikan kepala keluarga, ketergantungan masyarakat pada alam, kondisi geografis dan curah hujan, adanya biaya dalam proses ritual adat dan terbatasnya akses terhadap modal, serta kemiskinan di desa lebih besar daripada kota. Sedangkan hasil penelitian penyebab kemiskinan di kota dilakukan beberapa peneliti, yakni Harlik dkk (2013), Khabibi (2013), Busra (2011). Hasil penelitian menunjukkan penyebab kemiskinan di kota diantaranya tingkat pendidikan, tingkat pengangguran, PDRB, upah minimum kab/kota dan belanja public. Namun faktor tingkat pendidikan tidak berpengaruh signifikan terhadap tingkat kemiskinan di kota. Hal ini berdasarkan hasil penelitian Rusdarti dan Lesta (2013). Untuk tingkat propinsi, hasil penelitian Al Jundi (2014) menunjukkan faktor penyebab kemiskinan di propinsi Indonesia adalah PDRB, lama sekolah, UMR, tingkat pengangguran dan inflasi.

Berdasarkan hasil-hasil penelitian tersebut dapat disimpulkan bahwa tingkat kemiskinan di desa lebih disebabkan oleh ketergantungan pada kondisi alam, karena hampir sebagian penduduknya bekerja di sektor pertanian dan perkebunan dengan tingkat pendidikan rendah. Sedangkan untuk wilayah kota dan provinsi, penyebab kemiskinan lebih kompleks, karena mencakup tingkat pendidikan (tidak signifikan pada beberapa peneliti) serta indikator makro ekonomi (inflasi, pengangguran dan PDRB).

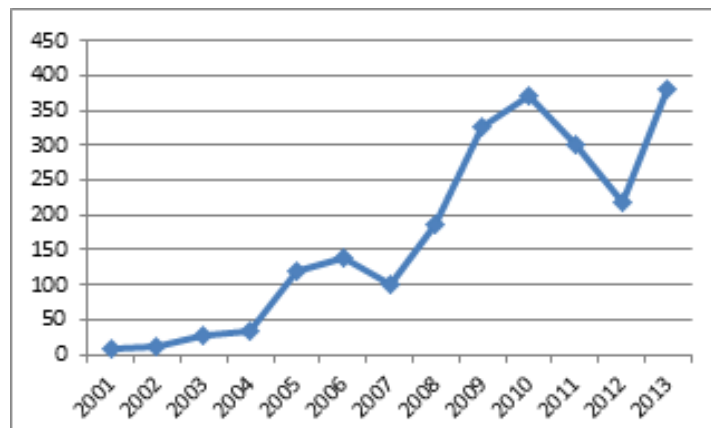

Grafik 3. Trend Jumlah Terpidana Kasus Korupsi di Indonesia (CegahKorupsi.feb.ugm.ac.id)

Kemiskinan menjadi permasalahan dari waktu ke waktu yang terjadi baik di tingkat desa, kota hingga propinsi. Untuk mengatasi permasalahan tersebut pemerintah berupaya meningkatkan pertumbuhan ekonomi melalui pembangunan di berbagai sektor. Hal ini bertujuan untuk membuka akses ekonomi bagi seluruh daerah di Indonesia. Indikator yang dapat digunakan untuk menilai upaya pemerintah dalam pengentasan kemiskinan adalah IPM (Indeks Pembangunan Manusia). Faktor lain yang patut dijadikan indikator kebijakan pemerintah dalam upaya mengurangi tingkat kemiskinan di Indonesia adalah pendapatan per kapita serta inflasi. Inflasi merupakan instrument pemerintah dalam menjaga daya beli masyarakat.

Dana yang dialokasikan pemerintah untuk pembangunan tidaklah sedikit. Namun seiring dengan maraknya pembangunan di propinsi-propinsi di Indonesia, khususnya setelah masa krisis finansial tahun 2008, menimbulkan permasalahan baru yang menghambat pertumbuhan ekonomi. Dan tentu saja menghambat program pengentasan kemiskinan. Permasalahan tersebut adalah tindak korupsi yang makin meningkat tiap tahunnya seiring dengan meningkatnya anggaran pembangunan oleh pemerintah.

Mengacu pada data KPK (Komisi Pemberantasan Tindak Korupsi) menunjukkan bahwa jumlah perkara kasus korupsi di tahun 2013 telah meningkat dua kali lipat dibanding tahun 2012. Tahun 2012 sebanyak 49 perkara menjadi 70 kasus di tahun 2013. Meningkatnya perkara korupsi di tahun 2013 disebabkan oleh meningkatnya perkara korupsi di beberapa daerah, khususnya didominasi daerah ibu kota dan wilayah Jawa-Sumatera. Daerah yang memiliki tingkat perkara korupsi tertinggi adalah di pemerintahan pusat, DKI Jakarta dan Jawa Barat. Ditinjau dari jenis pekerjaan, terpidana tingkat korupsi didominasi oleh birokrasi pemerintahan (PNS) sebesar 44\% (CegahKorupsi.feb.ugm.ac.id)

Ditengah upaya pengentasan kemiskinan muncul permasalahan korupsi yang telah menghambat proses pembangunan ekonomi di Indonesia. Oleh karena itu perlu diteliti lebih dalam dampak tindak pidana korupsi terhadap upaya pengentasan kemiskinan diseluruh propinsi di Indonesia. Faktor lainnya yang patut menjadi pertimbangan pemerintah dalam merumuskan permasalahan kemiskinan dan dirancang solusi yang tepat penanggulangannya adalah indikator makro ekonomi suatu negara 
dan faktor pembangunan manusia (IPM) sebagai cerminan kualitas SDM Indonesia. Beberapa penelitian tentang tingkat kemiskinan dengan mempertimbangkan faktor korupsi di Indonesia dilakukan oleh Negara \& Nasrudin (2013), Rahayu (2012). Hasil penelitian keduanya menjelaskan bahwa tidak terdapat pengaruh yang signifikan antara tindak korupsi dengan tingginya tingkat kemiskinan di Indonesia. Namun pengaruh tindak korupsi terhadap meningkatnya tingkat kemiskinan dapat ditunjukkan di luar negeri, seperti Nigeria oleh peneliti Ajisafe (2016). Penelitian lainnya yang menunjukkan adanya hubungan antara tindak korupsi terhadap tingkat kemiskinan suatu negara diantaranya Negin dkk (2010), Aina dan Abuja (2014), Gupta. S, Hamid, D dan Alonso (1998), Justesen dan Christian (2012) dan Gonva (2012). Beberapa hasil penelitian tersebut dapat dijadikan referensi untuk menilai seberapa besar keterkaitan antara tingkat korupsi beserta faktor lainnya terhadap tingkat kemiskinan di Indonesia.

\section{TUJUAN PENULISAN}

Berdasarkan uraian permasalahan kemiskinan di Indonesia, penelitian ini bertujuan untuk memahami faktor penyebab kemiskinan di Indonesia, melalui pendekatan indikator makro ekonomi, IPM dan korupsi. Selanjutnya dari model kemiskinan tersebut, dapat digunakan untuk mengetahui seberapa besar dampak korupsi terhadap tingkat kemiskinan di Indonesia dibanding faktor lainnya. Serta dapat digunakan untuk menggambarkan tingkat kemiskinan antar propinsi di Indonesia.

\section{METODE PENELITIAN}

Penelitian tingkat kemiskinan di Indonesia inimenggunakan data panel, yakniberupa data tahun dan data individu. Metode data panel digunakan dalam penelitian ini merujuk pada hasil-hasil penelitian sebelumnya yang mampu menjelaskan hubungan antara tingkat kemiskinan dan korupsi. Data tahun yang digunakan dalam penelitian ini dimulai tahun 2009 hingga 2013. Pemilihan tahun penelitian didasarkan atas pertimbangan tahun setelah terjadinya krisis finansial di tahun 2008 hingga 2013 yang mewakili masa sebelum adanya program-program social dari pemerintah (Kartu Indonesia Pintar, Kartu Indonesia Sehat d1l). Data individu yang digunakan sebanyak 28 propinsi yang mewakili wilayah Indonesia dibagian pulau
Sumatera dan Jawa-Bali serta wilayah luar pulau Sumatera dan Jawa-Bali. Pengolahan data panel menggunakan software STATA 12.

Variabel-variabel yang digunakan dalam model kemiskinan di Indonesia dibedakan menjadi dua variable, yakni variable dependen : tingkat kemiskinan per propinsi (\%), dan variable independen terdiri dari : IPM per propinsi, Inflasi (\%) dan PDRB per kapita setiap propinsi (indikator makro ekonomi), jumlah penduduk dan tindak korupsi (menggunakan data jumlah terpidana kasus tindak korupsi). Persamaan model panel yang digunakan dalam penelitian ini adalah

$$
\begin{aligned}
\mathrm{TK}_{\mathrm{ij}}= & \alpha_{0}+\alpha_{1} \text { Korup }_{\mathrm{ij}}+\alpha_{2} \text { PDRBc }_{\mathrm{ij}} \\
& \alpha_{3} \text { Penduduk }_{\mathrm{ij}}-\alpha_{4} \mathrm{PMM}_{\mathrm{ij}} \\
& \alpha_{5} \text { Inflasi }_{\mathrm{ij}}+\varepsilon
\end{aligned}
$$

\section{Keterangan :}

$\mathrm{TK}_{\mathrm{ij}}$ (Tingkat Kemiskinan Propinsi ke-i pada tahun ke- j), Korup ${ }_{\mathrm{ij}}$ ( tingkat tindak pidana nasional pada propinsi ke-i tahun ke-j), PDRBc (Pendapatan daerah per kapita propinsi ke-i pada

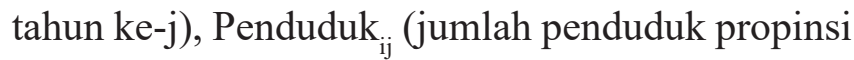

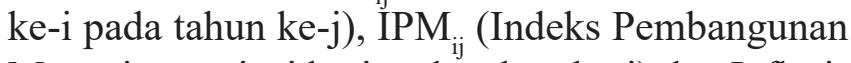
Manusia propinsi ke-i pada tahun ke-j) dan Inflasi $_{i j}$ (tingkat inflasi nasional pada propinsi ke-i tahun ke-j)

Data-data yang digunakan dalam penelitian ini menggunakan data yang bersumber dari : BPS (Badan Pusat Statistik Indonesia), data publikasi dari kementrian keuangan RI dan website UGM berkaitan dengan data korupsi di Indonesia.

\section{HASIL DAN ANALISIS}

Berdasarkan data tingkat kemiskinan per propinsi di Indonesia menunjukkan bahwa tingkat kemiskinan tertinggi didominasi oleh wilayah luar pulau Sumatera dan Jawa-Bali. Propinsi yang memiliki tingkat kemiskinan tertinggi adalah Papua. Hal ini dapat dinilai wajar mengingat lambatnya pembangunan ekonomi di wilayah tersebut. Meskipun kekayaan alam yang dimiliki Papua merupakan salah satu yang terbesar di Indonesia, pada kenyataannya tidak mampu untuk mengatasi permasalahan kemiskinan masyarakatnya. Artinya permasalahan yang dihadapi di Papua adalah kurangnya pembangunan ekonomi wilayah, sehingga berdampak pada kurangnya akses masyarakat setempat dalam mendapatkan pendidikan, kesehatan dan kehidupan 
yang layak, serta akses kemudahan ekonomi (modal dan keuangan). Akibatnya kekayaan alam yang melimpah tidak dapat dimanfaatkan dengan optimal. Dalam hal ini pemerintah dapat dengan cepat dan tegas dalam mengambil keputusan untuk menanggulangi permasalahan tersebut dengan percepatan pembangunan daerah di wilayah Papua.

Berbeda halnya ketika tingkat kemiskinan tinggi terjadi di wilayah dengan tingkat pembangunan cukup tinggi, yakni seperti propinsi daerah istimewa Yogyakarta. Hal ini ditunjukkan dengan nilai IPM yang tinggi diikuti dengan tingginya tingkat kemiskinan di propinsi tersebut. Kenyataan ini termasuk kondisi yang tidak umum yang seharusnya terjadi. Artinya dengan tingkat kualitas hidup layak seharusnya dapat menekan tingkat kemiskinan di propinsi tersebut. Terdapat faktor lain yang menjadi penyebab kemiskinan di propinsi Yogyakarta. Mengingat bahwa dukungan ekonomi telah dipenuhi oleh pemerintah, maka kemungkinan besar tingginya tingkat kemiskinan di Yogyakarta adalah faktor non-ekonomi, yakni social-budaya masyarakat setempat dalam memandang cara hidup yang lebih sederhana dibanding daerah-daerah lainnya di Indonesia. Faktor inilah yang tidak terlihat dalam bentuk data kuantitatif di dalam model regresi.

Fenomena tingkat kemiskinan juga terjadi di Ibu kota Negara Indonesia, yakni propinsi DKI Jakarta, dimana dengan tingkat IPM yang tinggi dan tingkat kemiskinan lebih rendah dibanding propinsi lain, namun tingkat korupsinya lebih tinggi dibanding propinsi lainnya. Kenyataan ini bertolak belakang dengan kondisi di Yogyakarta, seharusnya dengan tingkat kualitas hidup yang layak dan tingkat kemiskinan yang rendah DKI Jakarta tergolong propinsi yang mapan. Artinya sebagian warganya tergolong memiliki kehidupan yang layak secara ekonomi atau berkecukupan. Namun pada kenyataannya tingkat korupsi yang tinggi dapat menggambarkan sebagian warganya masih merasa kekurangan secara ekonomi. Dengan kata lain tingkat korupsi mencerminkan kebutuhan lain yang tergolong non-ekonomi, yakni persepsi akan kehidupan yang lebih dari cukup dan tuntutan materi yang berlebih untuk memuaskan keinginan yang tidak terbatas. Grafik IPM ditunjukkan pada grafik 4 dan 5 .

Gambaran kondisi kemiskinan tersebut membuat penelitian ini memasukkan unsur nonekonomi untuk mendapatkan model kemiskinan

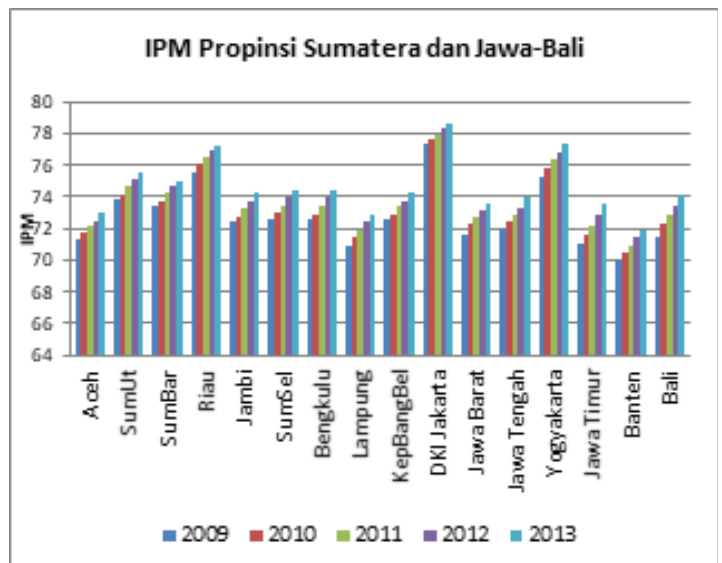

Grafik 4. IPM Propinsi Sumatera dan Jawa-Bali

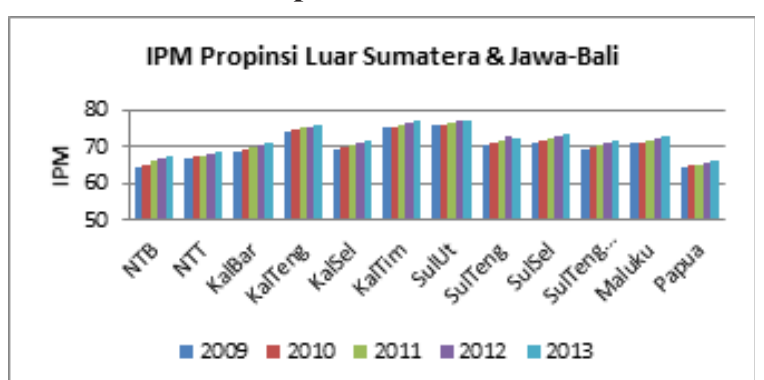

Grafik 5. IPM Propinsi Luar Sumatera dan Jawa-Bali yang terbaik dan mencerminkan realita yang terjadi di Indonesia. Variable korupsi digunakan untuk menangkap faktor non-ekonomi. Hasil regresi dengan menggunakan data panel ditampilkan pada table 1.

Tabel 1. Pemilihan Model Kemiskinan Propinsipropinsi di Indonesia yang Terbaik

\begin{tabular}{|c|c|c|}
\hline Uji Model & Hasil & Keterangan \\
\hline $\begin{array}{l}\text { Fixed effect } \\
\text { vs PLS }\end{array}$ & $\begin{array}{l}F(27,107)= \\
195.95 \\
\text { Prob }>F= \\
0.0000\end{array}$ & $\begin{array}{l}\text { Tolak Hipotesa, } \\
\text { Model yang } \\
\text { terbaik adalah } \\
\text { Fixed effect }\end{array}$ \\
\hline $\begin{array}{l}\text { Fixed effect } \\
\text { vs Random } \\
\text { effect }\end{array}$ & $\begin{array}{l}\text { chi } 2=22.44 \\
\text { Prob }>\text { chi } 2= \\
0.0004\end{array}$ & $\begin{array}{l}\text { Tolak Hipotesa, } \\
\text { Model yang } \\
\text { terbaik adalah } \\
\text { Fixed effect }\end{array}$ \\
\hline
\end{tabular}

Sumber : hasil perhitungan dengan STATA 12

Pemilihan model panel dilakukan untuk mendapatkan model yang terbaik dari tiga alternative model panel data, yakni : fixed effect, random effect dan pooled least squared (PLS). Pengujian pertama dilakukan untuk memilih antara model FE dan PLS dengan menggunakan ujiChow. Hasil perhitungan statistic menunjukkan nilai probabilitas F-test lebih kecil dari nilai alpha (tingkat kepercayaan) 1\%. Hal ini menunjukkan tolak Ho, artinya model yang terbaik dari keduanya 
Tabel 2. Hasil Pengujian Asumsi Klasik

\begin{tabular}{|c|c|c|}
\hline $\begin{array}{l}\text { Uji Asumsi } \\
\text { Klasik }\end{array}$ & Hasil Pengujian & Keterangan \\
\hline $\begin{array}{l}\text { 1. Heterokeda } \\
\text { stisitas }\end{array}$ & $\begin{array}{l}\operatorname{chi} 2(28)=1374.74 \\
\text { Prob }>\text { chi } 2= \\
0.0000\end{array}$ & $\begin{array}{l}\text { Tolak Hipotesa, } \\
\text { Terdapat } \\
\text { permasalahan } \\
\text { heterokesdastisitas }\end{array}$ \\
\hline 2.Autokorelasi & $\begin{array}{l}F(1,27)=24.709 \\
\text { Prob }>F=0.0000\end{array}$ & $\begin{array}{l}\text { Tolak Hipotesa, } \\
\text { Terdapat } \\
\text { permasalahan } \\
\text { Autokorelasi }\end{array}$ \\
\hline $\begin{array}{l}\text { 3. Multikolinea } \\
\text { ritas }\end{array}$ & $\begin{array}{l}\text { Terdapat } 2 \text { variabel } \\
\text { (Pidana dan Inflasi } \\
\text { Nilai VIF diatas } 10 \text { ) } \\
\text { Pidana, vif }=15.68 \\
\text { Inflasi, vif }=11,68\end{array}$ & $\begin{array}{l}\text { Nilai VIF diatas } \\
10 \text { menunjukkan } \\
\text { terdapat } \\
\text { permasalahan } \\
\text { multikolinearitas }\end{array}$ \\
\hline
\end{tabular}

adalah model FE. Pengujian tidak berhenti sampai disini, diperlukan pengujian kembali terhadap alternative model ketiga, yakni RE dengan menggunakan uji Hausman. Hasil perhitungan statistic menunjukkan nilai probabilitas Chi2 lebih kecil dari tingkat kepercayaan $1 \%$. Artinya hipotesa ditolak, sehingga model yang terbaik tetap FE. Dari kedua pengujian tersebut telah meyakinkan secara statistic bahwa model kemiskinan Indonesia dapat diterangkan oleh model FE (Fixed effect).

Langkah selanjutnya setelah mendapatkan model terbaik adalah perlunya dilakukan pengujian asumsi klasik terhadap model terpilih. Hal ini bertujuan agar hasil estimasi dari model terpilih benar-benar dapat dijadikan acuan dalam menilai kondisi kemiskinan Indonesia yang sesungguhnya. Artinya koefisien-koefisien baik intersep maupun slope dari model regresi dapat dipakai dalam menilai tingkat kemiskinan di Indonesia dan sebagai acuan untuk menilai tingkat kemiskinan di masa yang akan datang.

Terdapat tiga kemungkinan pelanggaran dalam asumsi klasik, yakni : adanya heterokedastisitas, autokorelasi dan multikolinearitas. Hasil pengujian ketiga bentuk pelanggaran tersebut ditampilkan pada tabel 2 .

Dari ketiga hasil pengujian menunjukkan bahwa terdapat permasalahan pelanggaran asumsi klasik dari model FE, yakni terdapat permasalahan heterokedastisitas (varian pada model FE yang tidak sama), autokorelasi (terdapat hubungan error antar waktu) dan multikolinearitas. Dengan demikian perlu dilakukan perbaikan pada model FE dengan menggunakan GLS (General Least Squared). Model perbaikan ini menggunakan asumsi bahwa varian error dalam model tidak diketahui dan digunakan untuk membuat model terbebas dari ketiga asumsi pelanggaran tersebut. Sehingga dalam hal ini model FE menjadi FE GLS. Persamaan regresi dari model FE GLS ditampilkan di bawah ini :

$\mathrm{TK}=20,1006+0,0101$ Korup $+0,00006 P D R B c-$ 0,0005 Penduduk $-0,7504 I P M * \mathrm{D}-0,2743$ Inflasi

Prob $>$ chi2 $=0.0000, \quad$ Wald chi2 $(32)=8553.62$ t-stat (P-Value) :

Korup $(0,000)$, PDRBc $(0,582)$, Inflasi $(0,000)$, IPM $(0,000)$, Penduduk $(0,027)$

Berdasarkan nilai probabilitas chi2 sebesar 0,0000 menunjukkan nilai yang lebih kecil dari tingkat kepercayaan 1\%. Artinya model FE GLS secara keseluruhan dapat menjelaskan tingkat kemiskinan masing-masing propinsi di Indonesia. Model FE GLS dapat menjelaskan perbedaan tingkat kemiskinan yang berbeda-beda dari setiap propinsi. Nilai tingkat kemiskinan yang dihasilkan merupakan nilai awal untuk menilai perbedaan 
Tabel 3. Rangking Tingkat Kemiskinan (\%)

Terendah Propinsi Sumatera dan Jawa-Bali

\begin{tabular}{|c|l|c|}
\hline Ranking & $\begin{array}{c}\text { Propinsi Pulau } \\
\text { Sumatera dan Jawa } \\
\text { (Bali) }\end{array}$ & $\begin{array}{c}\text { Nilai Awal Tingkat } \\
\text { Kemiskinan (\%) }\end{array}$ \\
\hline 1 & Kep.Bangka Belitung & 3,93 \\
2 & DKI Jakarta & 4,84 \\
3 & Jambi & 7,80 \\
4 & Sumatera Barat & 9,01 \\
5 & Riau & 9,39 \\
6 & Banten & 10,03 \\
7 & Sumatera Utara & 15,74 \\
8 & Yogyakarta & 15,95 \\
9 & Sumatera Selatan & 16,33 \\
10 & Bengkulu & 16,45 \\
11 & Lampung & 19,58 \\
12 & Aceh & 20,10 \\
13 & Jawa Tengah & 31,56 \\
14 & Jawa Barat & 32,57 \\
15 & Jawa Timur & 32,84 \\
16 & Bali & 59,09 \\
\hline
\end{tabular}

Tabel 4. Rangking Tingkat Kemiskinan (\%)

Terendah Propinsi Luar Sumatera dan Jawa-Bali

\begin{tabular}{|c|l|c|}
\hline Ranking & $\begin{array}{c}\text { Propinsi Luar Pulau } \\
\text { Jawa dan Sumatera }\end{array}$ & $\begin{array}{c}\text { Nilai Awal Tingkat } \\
\text { Kemiskinan (\%) }\end{array}$ \\
\hline 17 & Kalimantan Selatan & 57,55 \\
18 & Kal-Barat & 61,21 \\
19 & Kal-Tengah & 61,94 \\
20 & Kal-Timur & 62,96 \\
21 & Sulawesi Utara & 65,24 \\
22 & Sulawesi Selatan & 67,05 \\
23 & Sulawesi Tenggara & 67,65 \\
24 & Sulawesi Tengah & 69,88 \\
25 & NTB & 70,48 \\
26 & NTT & 72,55 \\
27 & Maluku & 75,56 \\
28 & Papua & 80,94 \\
\hline
\end{tabular}

tingkat kemiskinan dari masing-masing propinsi kurang dari 5\%.

tanpa dipengaruhi oleh variable independen.

Tabel 3 dan 4 menunjukkan perbedaan tingkat kemiskinan dari masing-masing propinsi. Hal ini bermanfaat untuk menilai seberapa besar kondisi tingkat kemiskinan masing-masing propinsi. Untuk wilayah pulau Sumatera dan Jawa-Bali, terlihat bahwa propinsi dengan tingkat kemiskinan terendah adalah Kepulauan Bangka Belitung, kemudian diikuti Daerah Khusus Ibukota Jakarta. Keduanya memiliki tingkat kemiskinan
Propinsi dengan tingkat kemiskinan tertinggi ditunjukkan dengan ranking terendah adalah propinsi Bali sebesar 59,09\%. Hasil ini cukup mengejutkan karena berdasarkan data mentah tingkat kemiskinan, Yogyakarta merupakan propinsi dengan tingkat kemiskinan yang tinggi. Kondisi tersebut terjadi karena hasil regresi dari model merupakan hasil pengolahan data tingkat kemiskinan antar propinsi, dengan menggunakan nilai dasar sebagai pembanding adalah tingkat 
kemiskinan propinsi Aceh. Nilai dasar yang dimaksud adalah nilai intercept dari persamaan regresi model FE GLS.

Berdasarkan hasil regresi model kemiskinan tersebut, menunjukkan bahwa jika dibandingkan dengan propinsi-propinsi lainnya, Yogyakarta tergolong memiliki tingkat kemiskinan yang lebih rendah dibanding propinsi Jawa lainnya (Jawa Timur, Jawa Tengah dan Jawa Barat).

Seperti telah diungkapkan sebelumnya bahwa terdapat faktor non-ekonomi yang mendasari penyebab tingginya tingkat kemiskinan di Yogyakarta. Hal ini dapat tercermin dalam model regresi FE GLS, dimana Yogyakarta berada pada ranking ke-8 dengan tingkat kemiskinan cenderung rendah sebesar $15,95 \%$.

Tingkat kemiskinan terendah di luar propinsi Sumatera dan Jawa-Bali didominasi oleh propinsi Kalimantan. Kalimantan Selatan menduduki peringkat teratas untuk tingkat kemiskinan terendah di wilayah luar pulau Sumatera dan Jawa-Bali. Walaupun tergolong terendah di wilayah luar Sumatera dan JawaBali, namun tingkat kemiskinan sebesar 57,55\% merupakan tingkat kemiskinan yang tergolong tinggi untuk ukuran propinsi Sumatera dan JawaBali.

Propinsi Papua menduduki peringkat terakhir sebagai propinsi dengan tingkat kemiskinan tertinggi dibanding propinsi lainnya, sebesar 80,94\%. Secara umum terlihat bahwa dibutuhkan upaya yang keras bagi propinsi Papua untuk menurunkan tingkat kemiskinan daerah, sehingga dapat mengejar ketimpangan dengan propinsi lainnya. Nilai-nilai tersebut merupakan nilai awal tingkat kemiskinan dari masing-masing propinsi dalam model FE GLS.

Analisis Hubungan antara Indikator Makro Ekonomi terhadap Tingkat Kemiskinan Propinsi-Propinsi Indonesia

Indikator makro ekonomi digunakan untuk melihat peran pemerintah pusat terhadap upaya pengentasan kemiskinan di seluruh propinsi. Variabel-variabel yang mencerminkan indikator makro ekonomi adalah pendapatan daerah per kapita dan inflasi. Hasil regresi FE GLS (terlampir) menunjukkan bahwa variabel PDRB per kapita berpengaruh positif terhadap tingkat kemiskinan di Indonesia dengan asumsi variabel lain cateris paribus. Akan tetapi secara statistik pengaruhnya tidak signifikan terhadap peningkatan kemiskinan.
Hal ini dikarenakan nilai P-Value dari t-stat sebesar 0,582 lebih besar dari tingkat toleransi kesalahan 5\%. Artinya dampak positif dari kenaikan pendapatan daerah tidak terbukti secara statistic mempengaruhi peningkatan kemiskinan di propinsi-propinsi. Dapat dikatakan bahwa pendapatan seseorang bukan merupakan jaminan tingkat kesejahteraan telah tercapai. Hal tersebut tergantung pada individu dalam mengelola keuangannya. Jika pengeluaran lebih besar dari pendapatan, maka berapapun pendapatan tidak akan pernah cukup. Bila kondisi ini berlangsung terus menerus dari waktu ke waktu akan berdampak pada lemahnya ekonomi dan akhirnya akan meningkatkan tingkat kemiskinan seseorang. Hal ini penting menjadi perhatian pemerintah dalam memandang pendapatan per kapita bukanlah cara yang tepat menilai tingkat kemiskinan seseorang, namun kemampuan pengelolaan keuangan yang baik menjadi faktor yang patut dipertimbangkan dalam menilai tingkat kemiskinan suatu daerah. Berdasarkan hasil penelitian tersebut, maka kemungkinan faktor yang dapat dijadikan indikator dalam menilai tingkat kemiskinan seseorang adalah jumlah tabungan per kapita.

Indikator makro ekonomi selanjutnya adalah tingkat inflasi. Pemerintah selalu berupaya untuk menjaga stabilitas harga melalui inflasi yang terkendali. Hasil regresi menunjukkan inflasi berpengaruh signifikan terhadap tingkat kemiskinan di Indonesia. Nilai p-value sebesar 0,000 lebih kecil dari nilai alpha (toleransi kesalahan) 5\%. Artinya tolak H0, bahwa terdapat pengaruh signifikan dari kenaikan tingkat inflasi sebesar $1 \%$ terhadap penurunan tingkat kemiskinan propinsi-propinsi di Indonesia sebesar $0,2743 \%$. Kenaikan tingkat inflasi ini dibutuhkan sebagai gambaran meningkatnya pertumbuhan ekonomi Indonesia. Dalam hal ini dapat dijadikan acuan bagi pemerintah dalam menetapkan tingkat inflasi yang tepat dan efektif dalam mengurangi tingkat kemiskinan propinsi-propinsi di Indonesia. Namun tentu harus ditunjang dengan tetap menjaga stabilitas harga, agar daya beli masyarakat tidak mengalami penurunan.

\section{Analisis Hubungan antara Jumlah Penduduk Propinsi-Propinsi di Indonesia terhadap Tingkat Kemiskinan di Indonesia}

Hasil regresi model kemiskinan dapat menjelaskan hubungan jumlah penduduk dengan tingkat kemiskinan. Hal ini ditunjukkan dengan 
nilai p-value sebesar 0,027 lebih kecil dari nilai alpha 5\%, yang artinya tolak hipotesa Ho. Bahwa terdapat pengaruh negative dan signifikan dari peningkatan jumlah penduduk sebesar seribu orang terhadap penurunan tingkat kemiskinan sebesar $0,0005 \%$. Secara jumlah persentase, terlihat bahwa dampak kenaikan jumlah penduduk terhadap penurunan tingkat kemiskinan relative kecil. Namun cukup efektif dalam upaya untuk mengentaskan kemiskinan di propinsi-propinsi Indonesia.

Akan tetapi hal yang perlu dicermati adalah besaran jumlah penduduk yang manakah yang mampu secara efektif menurunkan tingkat kemiskinan. Penduduk produktif dari suatu propinsi merupakan salah satu indikator yang dapat mencerminkan hubungan peningkatan jumlah penduduk terhadap penurunan tingkat kemiskinan. Semakin banyak jumlah presentase penduduk produktif (usia muda), maka kemampuan daerah dalam mengelola asset serta upaya pengembangan daerah makin terbuka lebar. Asset yang paling berharga bagi suatu negara adalah sumberdaya manusia. Maka dengan besarnya jumlah penduduk produktif merupakan keuntungan tersendiri bagi daerah itu sendiri.

Berdasarkan data tahun 2014 Jumlah persentase pemuda (usia 17-30 tahun) terbesar ada di pulau Jawa, sebesar 55,95\% dari total jumlah pemuda di Indonesia (Bappenas.go.id). Besarnya jumlah pemuda di pulau Jawa seharusnya dapat disadari oleh pemerintah sebagai asset daerah yang harus dibangun, dididik dan diarahkan agar nantinya dapat berkontribusi bagi pembangunan daerah di pulau Jawa. Sehingga pada akhirnya diharapkan dapat mendukung upaya pengentasan kemiskinan di wilayah tersebut.

Analisis Hubungan antara IPM propinsi Sumatera dan Jawa-Bali (Dalam dan Luar) terhadap Tingkat Kemiskinan di Indonesia

Berdasarkan hasil regresi model FE GLS, terlihat bahwa faktor yang paling berkontribusi dalam penurunan tingkat kemiskinan di Indonesia adalah IPM (Indeks Pembangunan Manusia). Hal ini ditunjukkan dengan nilai $\mathrm{p}$-value 0,000 yang artinya hipotesa nol berhasil ditolak. Terdapat pengaruh negative dan signifikan dari peningkatan IPM terhadap penurunan tingkat kemiskinan di Indonesia. Namun dampak yang ditimbulkan dari peningkatan IPM terhadap penurunan tingkat kemiskinan berbeda antara propinsi Sumatera dan
Jawa-Bali dengan propinsi diluar Sumatera dan Jawa-Bali. Hal ini ditunjukkan oleh nilai koefisien sebesar 0,7504, yang berarti bahwa kenaikan nilai IPM di luar propinsi Sumatera dan Jawa-Bali lebih besar $0,7504 \%$ dampaknya terhadap penurunan tingkat kemiskinan dibanding wilayah di propinsi Sumatera dan Jawa-Bali. Propinsi NTB merupakan salah satu propinsi di luar pulau Sumatera dan Jawa-Bali dengan laju pertumbuhan IPM diatas 1\%. Hal ini dapat terus ditingkatkan untuk mempercepat upaya pengentasan kemiskinan yang tinggi di wilayah tersebut.

Besarnya dampak IPM terhadap upaya penurunan tingkat kemiskinan di luar pulau Sumatera dan Jawa-Bali merupakan hal yang positif. Karena tingkat kemiskinan di Indonesia hampir sebagian besar berada di luar pulau Sumatera dan Jawa-Bali. Sehingga dengan peningkatan kualitas manusia melalui pembangunan berbasis pengembangan dan peningkatan akses pendidikan, kesehatan serta dalam mendukung kehidupan yang lebih layak, dapat efektif menurunkan tingkat kemiskinan. Hal ini juga berarti akan mengurangi ketimpangan pembangunan daerah antara propinsi di Sumatera dan Jawa-Bali dengan propinsi di luar Sumatera dan Jawa-Bali.

Hasil penelitian ini juga membuktikan bahwa sumber daya manusia merupakan asset yang sangat penting bagi kemajuan suatu daerah. Sehingga bagi pemerintah daerah perlu mendorong dan menjamin peningkatan kualitas warganya dengan baik. Investasi yang tidak ternilai jika pemerintah berkomitmen untuk mengembangkan kualitas manusia di daerahnya masing-masing, khususnya propinsi di luar Sumatera dan JawaBali. Hasil dari investasi tersebut akan dinikmati 10-20 tahun mendatang dalam wujud kehidupan yang lebih layak, mapan dan berkualitas. Inilah hakikat dari pembangunan seutuhnya, yakni membangun manusia Indonesia untuk menciptakan kesejahteraan bagi seluruh warganya tanpa kecuali.

Analisis Hubungan antara Jumlah Terpidana Korupsi terhadap tingkat kemiskinan propinsipropinsi di Indonesia

Sejak era reformasi focus pemerintah terhadap permasalahan-permasalahan socialekonomi makin terlihat. Terbentuknya KPK sebagai lembaga independen yang bertujuan memberantas tindak korupsi menjadi salah satu buktinya. Sebagian besar tindak korupsi dilakukan oleh aparat pemerintah pusat. Hal ini 
sungguh memprihatinkan ditengah kondisi tingkat kemiskinan yang masih tinggi dan ketimpangan antara pusat dan daerah belum kunjung merata. Oleh karena itu penting bagi pemerintah untuk mengetahui besaran dampak tindak korupsi terhadap tingkat kemiskinan di propinsi-propinsi Indonesia.

Hasil estimasi variabel korupsi dengan tingkat kemiskinan menunjukkan hubungan yang positif. Artinya semakin tinggi tindak korupsi menyebabkan makin meningkatnya tingkat kemiskinan di wilayah propinsi-propinsi Indonesia. Hal ini dibuktikan secara statistik melalui nilai $p$-value sebesar 0,000 lebih kecil dari tingkat toleransi kesalahan 5\%.

Besaran pengaruh tindak korupsi terhadap tingkat kemiskinan ditunjukkan oleh nilai koefisien 0,0101. Artinya peningkatan sebesar satu terpidana kasus korupsi akan berdampak pada makin meningkatnya tingkat kemiskinan sebesar $0,0101 \%$. Bisa dibayangkan jika jumlah terpidana korupsi meningkat tiap tahunnya, misalnya jika terjadi kenaikan terpidana kasus korupsi sebanyak 100 kasus, maka tingkat kemiskinan di Indonesia kan meningkat sebesar 1,01\%. Untuk itu ketegasan pemerintah secara hukum dalam memberantas tindak korupsi sangat diharapkan oleh seluruh rakyat Indonesia yang menginginkan pemerataan dan keadilan ekonomi.

Berdasarkan uraian hasil dan pembahasan di atas, menunjukkan terdapat keterkaitan antar variable penyebab tingkat kemiskinan di Indonesia. Hasil penelitian ini dapat dijadikan salah satu pertimbangan dalam menyusun rumusan program pengentasan kemiskinan di Indonesia. Dengan cara pemerintah dapat mulai membenahi fokus pembangunan daerah, yakni lebih focus pada pembangunan yang berhubungan langsung terhadap peningkatan kualitas SDM. Hal ini dapat dilakukan dengan memperluas akses pendidikan, kesehatan dan akses keuangan (modal) bagi seluruh masyarakat tanpa kecuali. Adanya reformasi ekonomi yakni perlakuan yang sama bagi seluruh rakyat Indonesia tanpa kecuali didalam mendapatkan akses ekonomi. Kesetaraan ini tidak hanya berlaku didalam hukum, di bidang ekonomi juga dibutuhkan kesetaraan. Sehingga diharapkan akan mengurangi penguasaan oleh sebagian elit saja (elite capture).

Upaya mendorong peningkatan kualitas manusia juga harus didukung dengan faktor kebijakan ekonomi pemerintah dalam hal stabilitas harga. Hal ini dapat dilakukan dengan menjaga tingkat inflasi yang tepat sesuai dengan target pertumbuhan ekonomi dan mempertimbangkan daya beli masyarakat. Pertumbuhan ekonomi sangat dibutuhkan, namun juga jangan sampai mengorbankan daya beli masyarakat, khususnya rakyat miskin.

Untuk medukung kedua program tersebut, pemerintah juga perlu mempersiapkan perkembangan penduduk usia produktif dengan bekal pendidikan, baik pendidikan formal. Informal maupun yang paling penting adalah pendidikan karakter atau akhlak. Hal ini bertujuan untuk menciptakan manusia Indonesia yang berkualitas dan berakhlak mulia. Jika hal ini bisa dilakukan, maka merupakan salah satu kontribusi dalam mendukung program pemberantasan tindak pidana korupsi. Menciptakan manusia yang berkualitas dan berakhlak mulia tidak dapat dilakukan dalam waktu sekejap. Dibutuhkan investasi yang cukup besar dalam mendukung tumbuh kembang manusia Indonesia dari mulai usia dini hingga dewasa. Oleh karena itu, dibutuhkan pemetaan penduduk sesuai dengan usia di seluruh propinsi di Indonesia. Hal ini akan memudahkan pemerintah daerah dalam merancang dan mempersiapkan penduduk usia muda (generasi muda) sesuai dengan waktu dan biaya yang dibutuhkan.

Faktor terakhir yakni korupsi merupakan faktor satu-satunya yang menyebabkan meningkatnya tingkat kemiskinan di Indonesia dibanding faktor-faktor lainnya. Artinya korupsi merupakan ancaman atau musuh bersama yang harus diberantas, karena telah menyebabkan kemiskinan yang makin tinggi. Upaya pemerintah saat ini untuk memberantas tindak korupsi secara hukum sudah cukup baik. Namun pemberantasan tindak korupsi tidak bisa dari satu aspek saja, dibutuhkan dukungan dari berbagai aspek. Selain pendidikan karakter seperti telah disebutkan di atas, dibutuhkan pula pendekatan secara psikologis dan sanksi social bagi pelaku tindak korupsi. Pendekatan secara psikologis yang dimaksud adalah tindak korupsi merupakan tindakan abnormal, karena secara ekonomi pelaku tindak korupsi tergolong berkecukupan bahkan tergolong menengah ke atas, namun masih merasa kekurangan secara ekonomi. Hal ini pada hakikatnya adalah kemiskinan yang sesungguhnya. Dalam arti kemiskinan yang dihadapi bukanlah persoalan 
ekonomi melainkan kemiskinan batin atau jiwa. Sehingga hal ini mempengaruhi tindakannya menjadi serba kekurangan ditengah kekayaan yang dimiliki.

\section{KESIMPULAN}

Hasil penelitian yang telah diuraikan di atas mampu menjawab tujuan penelitian, yakni faktor penyebab tingkat kemiskinan propinsi-propinsi di Indonesia secara statistik berpengaruh signifikan adalah IPM (Indeks Pembangunan Manusia), Indikator makroekonomi diwakili oleh tingkat inflasi, tindakan korupsi dan jumlah penduduk. Tindakan korupsi telah berdampak positif terhadap kenaikan tingkat kemiskinan di Indonesia sebesar $0,0101 \%$. Hanya faktor tindakan korupsi yang berdampak positif dan signifikan terhadap meningkatnya tingkat kemiskinan di Indonesia. Faktor pendapatan daerah (PDRB per kapita) juga berdampak positif terhadap tingkat kemiskinan, namun tidak signifikan. Bersumber dari hasil penelitian ini dapat dijadikan bahan pertimbangan bagi pemerintah dalam merumuskan program pengentasan kemiskinan di propinsi-propinsi di Indonesia. Dengan cara mendorong dan mendukung upaya pembangunan manusia untuk menciptakan manusia yang berkualitas. Wujud pembangunan manusia yang dimaksud adalah pembangunan akses-akses yang mendukung perkembangan dan kemajuan SDM Indonesia, khususnya bagi generasi muda. Perlu menjadi perhatian bahwa program pembangunan manusia ini harus lebih ditingkatkan didaerah-daerah yang tinggi tingkat kemiskinannya, seperti propinsi luar pulau Sumatera dan Jawa-Bali, serta propinsi di pulau Jawa (Jawa Tengah, Jawa Timur dan Jawa Barat). Pembangunan manusia ini merupakan pondasi bagi negara untuk mewujudkan masyarakat yang sejahtera dan adil bagi seluruh rakyat Indonesia tanpa kecuali, dengan karakter yang baik dan luhur.

\section{DAFTAR PUSTAKA}

Kaplale, R (2012), Faktor-faktor yang Mempengaruhi Tingkat Kemiskinan Di Kota Ambon (Studi Kasus di Dusun Kranjang Desa Waiyame Kec. Teluk Ambon dan Desa Waiheru Kec. Teluk Ambon Baguala Kota Ambon). Vol 1 No.1 Oktober 2012. Jurnal Agribisnis Kepulauan.
Harlik, Amir dan Hardiani (2013), Faktor-faktor yang Mempengaruhi Kemiskinan dan Pengangguran di Kota Jambi. Jurnal Perspektif Pembiayaan dan Pembangunan Daerah Vol. 1, No.2. Oktober.

Khabibi, A (2013), Analisis Faktor-Faktor yang Mempengaruhi Tingkat Kemiskinan (Studi Kasus $35 \mathrm{Kab} /$ Kota di Provinsi Jawa Tengah Tahun 2011). Skripsi. Fakultas Ekonomi. Universitas Sebelas Maret. Surakarta.

Rusdarti dan Sebayang, L.K (2013), Faktor-faktor yang Mempengaruhi Tingkat Kemiskinan di Provinsi Jawa Tengah. Jurnal Economia. Vol 9. No.1 April

Al Jundi, M (2014), Analisis Faktor yang Mempengaruhi Tingkat Kemiskinan Provinsi-Provinsi di Indonesia. Skripsi. Ilmu Ekonomi dan Studi Pembangunan. Fakultas Ekonomi dan Bisnis UNDIP.

Harahap, I (2002), Analisis Faktor-Faktor Penyebab Kemiskinan Masyarakat Desa (Studi Kasus Desa Bulucina Tarutung Sihoda-hoda dan Desa Gonting Jae. Kecamatan Barumun Tengah Kabupaten Tapanuli Selatan). Tesis. Program Pasca Sarjana. Universitas Sumatera Utara

Ajisafe, R.A (2016), Corruption and Poverty in Nigeria : Evidence From Ardl Bound Test and Error Correction Model. Journal of Emerging Trends in Economics and Management Sciences (JETEMS)

Negin. V, Rasyid Z. A and Hesam N (2010), The Causal Relationship Between Corruption and Poverty : A Panel Data Analysis. Munich Personal Repec Archive Paper No 24871. Posted 10 Sep 2010.

Aina dan Abuja (2014), How Corruption Contributes to Poverty. Best Paper Award. International Conference 2014. 19-20 December, Chittagong, Bangladesh. Organized by : Center for Research and Publication International Islamic University Chittagong 
Justesen and Christian. B (2012), Exploiting The Poor : Bureaucratic Corruption and Poverty In Africa. Afrobarometer Working Papers, No. 139

Gonfa. A (2011), Corruption, Governance and Poverty in Sub-Saharan Africa : Panel Evidence. Thesis. Master of Science in Economics. Addis ABABA University. School of Graduate Studies

Gupta. S, Hamid, D dan Alonso (1998). Does Corruption Affect Income Inequality and Poverty?. International Monetary Fund Working Paper.

Pradiptyo R, Partohap dan PramaShavira (2016).

Korupsi Struktural : Analisis Data Base Korupsi Versi 4 (2001-2015). Laboratorium Ilmu Ekonomi Departemen Ilmu Ekonomi. Fakultas Ekonomi dan Bisnis. UGM. CegahKrupsi.feb.ugm.ac.id

Bank of Indonesia, 2016. Laporan Inflasi (Indeks Harga Konsumen) http://www.bi.go.id/id/moneter/inflasi/data

Jumlah dan Persentase Penduduk Miskin, Garis Kemiskinan, Indeks Keparahan Kemiskinan (P2) Menurut Provinsi www.bps.go.id

Rahayu, I.P (2012). Pengaruh Korupsi Terhadap Kemiskinan di Indonesia. Program Studi S2 Ilmu Ekonomi dan Studi Pembangunan UGM. http://etd.repository.ugm.ac.id

Negara, G.M dan Nasrudin, R (2013). Analisis Hubungan Korupsi dan Kemiskinan Kabupaten/Kota di Indonesia. Program Studi Ilmu Ekonomi. Fakultas Ekonomi dan Bisnis UI. http://lontar.ui.ac.id/

Ainadan Abuja (2014), How Corruption Contributes to Poverty.Best Paper Award. International Conference 2014.19-20 December, Chittagong, Bangladesh. Organized by : Center for Research and Publication International Islamic University Chittagong
Justesen and Christian. B (2012), Exploiting The Poor : Bureaucratic Corruption and Poverty In Africa. Afrobarometer Working Papers, No. 139

Fraj,S.H and Amira L, 2015. Relationship between Corruption and Economic Growth : The Case of Developing Countries. International Journal of Economics, Commerce and Management. Vol III. Issue 9, September 2015. ISSN 23480386.

BREMpong, K.G 2002. Corruption, Economic Growth and Income Inequality in Africa. Economics of Governance. Econ. Gov. (2002) $3: 183-209$.

Indonesian Central Bureau of Statistics Human Development Index According to Province 1996-2013. www.bps.go.id.

Indonesian Central Bureau of Statistics. Amount of Poor Residents According to Provinces (2007-2017). www.bps.go.id.

Negin. V, Zakariah B.A Rashid and Hesam. N, 2011. The Causal Relationship Between Corruption and Poverty : A Panel Data Analysis. Journal of International Economics Review, 4 : 1(2011): 23-38. 